adult larve of allied genera. Indeed, this statement is perhaps too feebiy formulated, so important are many of the distinctions which have been traced. These differences, it should be noted, are not always in the same direction; for we have seen that caterpillars which in infancy are clothed with appendages of a unique and consipcious character, definitcly disposed, display, in mature life, irregularly distributed, scarcely perceptible i:arts, emitting simple and nearly microscopic hairs; while others, which in their earliest stage bore regular series of simple hairs, seated on little warts, become possessed, at maturity, of compound spines, surmounting inammulx, also definitely arranged, but occupying a very different position to the hairs of early life. So, too, we find some caterpillars which bear a tuberculated, irregular head in infancy, and a smooth and equal one at maturity; or the reverse, where the head is simple at birth, and neavily spined or cornute when full grown; others, again, rcmain almost unchanged through life. This latter condition of uniformity never applies to the appendages of the body, whether we consider their character alone or their disposition. Nor-the only other possible condition-do we ever find larvæ bearing only irregularly distributed, simple, minute hairs in infancy, and regularly arranged special appendages at maturity. incleed, $i$ : is doubtful whether such a phenomenon exists in Nature; since in the numerous and varied groups that have been examined, special dermal appendages have been found to be an invariable characteristc of embry onic larvæ.

August, 1871.

NOTES ON THE LARVA OF

ACRONYCTA OCCIDENTALIS, Grote.

BY W. SAUNDERS, LONDON, ONT.

THIs insect in the imago state closely rescmbles A psi, of Europe. and has been, and we believe still is, doubtfully regarded as identical by several eminent European entomologists. We thinks, however, that a comparison of the larval forms of the two insects will help to dispel any doubts which may be entertained regarding the dissimilarity of the species. The following description of the larva of occidentalis has already appeared in part, in the Annual Report of the Entomological Society of Ontario to the Commissioner of Agriculture for 1870 , where it is given. 
and, as we supposed at the time, correctly so, under the name of psi; but since probably but few of our readers will have seen that Report, and as the edition is sometime since exhausted, we shall reproduce the description here in a fuller form:-

Larva sparingly hairy, found feeding on plum, cherry and apple.

Head rather long, bilobed, somewhat flat in front; black, wirh yellowish dots at the sides, and with a few scattered whitish hairs.

Body above bluish-gray, with a wide slate-coloured uorsal band, having a central pale orange line from second to fifth segments. From fifth to eleventh inclusive, each segment is ornamented with a beautiful group of spots, placed in the dorsal band, two of them bright orange-one in front and one behind-and one on each side of a greenish metallic hue; each group being set in a nearly circular patch of velvety black. There are two lateral cream-coloured stripes, the upper one adjoining the dorsal band, these stripes growing indistinct towards the anterior and posterior segments, and down which extends, from each of the black dorsal patches, a short black curved line, having immediately behind its junction with the dorsal band a yellowish dot. The sides are marked more or less with dull ochrey spots, some of which form a broken band, close to the under surface. On the dorsal portion of twelfth segment is a dull black spot, considerably raised, forming a small hump; terminal segment flattened and blackish. Body sparingly covered with whitish hairs, which are distributed chiefly along the sides, close to the under surface.

Under surface dull greenish, feet black.

Described from several specimens; found in the early part of September, entered the chrysalis state from the 15 th to 20 th September, and produced the imago from the 6 th to the 8 th of June following.

Mr. E. Newman, in his valuable work called "British Moths," gives a very full description of the larva of $p s i$ as follows:-"The head of the caterpillar is rather wider than the second segment; the body is hairy with parallel sides, but humped on the back; the first hump is slender, long, erect, horn-like, and seated on the fifth segment; the second hump is shorter, broader, and on the twelfth segment. The head is black, hairy and shining; its divisions very convex; the second segment is black, with a very narrow median yellow line; the third, tourth, sixth, seventh. eigth, ninth, tenth and eleventh segments have a broad median yellow stripe, and there is a median square spot of the same colour on the hinder part of the twelfth segment; the horn-like hump on the fifth segment is 
intensely black, and clothed with crowded short black hairs, intermixed with scattered long ones; on each side of the median stripe is an equally broad jet black stripe, and in this on every segment, from the fifth to the twelfth both inclusive, are two transverse bright red spots, with two minute whitish warts between each pair, the warts emittıng black bristles; below the black stripe on each side is a broad gray stripe, emitting gray hairs, and including the black spiracles; this gray stripe is reddish on the anterior segments, the intensity of the red increasing towards the head. The belly, legs, and claspers are dingy flesh coloured. It feeds on white thorn, pear, and a variety of other trees."

The long, intensely black hump on the fifth segment, which is a very striking characteristic in spi, is entirely wanting in occidentalis, the coloration also is very different, the broad median yellow stripe, in the former from sixth to twelfth segments is also wanting in the latter. The circular black patches in the American species is represented in the European insect by a broad black stripe bordering the equally broad yellow one, the grouping and color of the clusters of small dorsal spots on each of these segments is also very different. In psi the black is bordered with a broad gray stripe becoming reddish on anterior segments, while in occidentalis the same portion is covered with two narrower cream colored stripes, becoming less distinct on the anterior segments. Many other minor points of difference might be educed, but these, we think, are sufficient to show that in the larval state these species are widely diverse.

The imago of occidentalis is said by Mr. Grote (see Proc. Ent. Soc. Phila., vol. 6, p. 16,) to differ from psi, "by" the paler color of primaries, which are more sparsely covered with scales, and their somewhat squarer shape. The reniform spot on the disk shows a bright testaceous tinge, and the ordinary spots are less approximate than in psi. The secondaries are dark grey, nearly unicolorus, a little paler in the male, and darker in either sex than its European analogue."

After a careful comparison of a number of bred specimens with the European insect we fail to see the validity of most of the distinctive points urged by $\mathrm{Mr}$ Grote. We have found the color of primaries to vary much, in some examples they have been darker, but in the majority they have been fully as light as those of $p s i$; nor can we see any difference in uninjured specimens with regard to the density of the scale covering. In some the wings are somewhat squarer, but it is a difference scarcely perceptible, and in other examples we have failed to detect it. The testa- 
ceous tinge in the reniform spot is perceptible in all the specimens we have seen, in some quite brignt, but in others exceedingly faint. The relative approximation of the ordinary spots varies so much in different individuals as to be of little distinctive value. The darker color of secondaries is, we believe, more uniform, and is quite characteristic 1 most instances, but in several male specimens we have been unable to trace any difference in this respect. There are two other small points of distinction, not memtioned by Mr. Grote, which we have thus far found invariable: in psi, the orbicular spot has a black border on the outer side; in occidentalis, this is wanting, or scarcely perceptible, or otherwisc replaced by a faint entire testaceous bordering. In psi, the inner black bordering of the reniform spot is double at its lower extremity, while in occidentalis we have never found it otherwise than single, and this much less distinct in most specimens. All these points of difference in the imago state, it must be admitted, are very slight and vague as compared with the striking dissimilarity of the insects in their respective larval forms.

\section{INSECTS OF THE NORTHERN PARTS OF BRITISH AMERICA COMPILED BY THE EDITOR.}

From Kirby's Fauna Boreali-Americana: Insecta.

(Continued from page 36.)

217. Trachys ACUducta Kirby.-Length of body 4 lines. Takerr by Capt. Hall in Nova Scotia.

[163.] Body oblong, punctured, hainy with scattered minute decum. bent bristles resembling little scales, of a bronzed and glossy copper colour. Front with a slight sinus: prothorax transverse, trilobed at the base; disk longitudinally convex and naked; sides hairy; surface in the disk covered with minutes transverse undulated iines curving upwards, and sides reticulated with them: scutellum transverse acuminated: elytra uneven, constricted before the middle, clouded and obsoletely banded. towards the apex with minute whitish bristles; tips rounded, serrulate: prosternum broad, a little constricted in the middle, rounded at the apex.

[164.] FAMILY PYTHIDAE.

218. Pytho Niger Kirby.-Plate vii., fig. 2.-Length of body $51 / 4^{-}$ $51 / 2$ lines. Several taken in Lat. $54^{\circ}$, and in the journey from New York to Cumberland-house. 